\title{
Review of Barriers to Engaging Black and Minority Ethnic Groups in Physical Activity in the United Kingdom
}

\author{
Sejlo A. Koshoedo (Corresponding Author) \\ Department of Public Health, University of Aberdeen \\ Medical School, Polwarth Building \\ Foresterhill, Aberdeen AB25 2ZD \\ Scotland, UK \\ Tel: 44-1224-559-007Ｅ-mail: s.koshoedo@abdn.ac.uk \\ Padam Simkhada \\ Lecturer in International Health \\ Department of Public Health, University of Aberdeen \\ Medical School, Polwarth Building \\ Foresterhill, Aberdeen AB25 2ZD, Scotland, UK
}

Tel: 44-1224-552-492Ｅ-mail: p.p.simkhada@abdn.ac.uk

Edwin R. van Teijlingen

Centre for Midwifery, Maternal \& Perinatal Health Research

School of Health \& Social Care Royal London House Christchurch Road

University of Bournemouth BU1 3LT Bournemouth, UK

Tel: 44-1202-961-564Ｅ-mail: vanteijlingen@bournemouth.ac.uk

\begin{abstract}
Introduction and Objective: The lower physical activity levels in Black and Minority Ethnic (BME) groups as compared with general population in the United Kingdom (UK) could relate to barriers to engaging these groups in physical activity. Hence, the aim to conduct a review to examine UK primary studies reporting barriers to engaging BME groups in physical activity. Method: This is a narrative review of literature from 1970 to 2008. The search looked for English literature from five bibliographic databases (MEDLINE, Embase, CINAHL, PsyINFO, Ethnicity and Health). Broad search terms 'physical activity and minority' were used and views from BME groups were considered in this review.

Results \& Conclusion: The search yielded 391 studies and 18 were finally included in the review. Our review identified 20 barriers clustered among four broad themes of: (a) perceived personal barriers; (b) socio-economic barriers; (c) cultural barriers; and (d) environmental barriers. Overcoming these barriers in these broad areas is important in development of sensitive multicultural health promotion addressing physical inequalities.
\end{abstract}

Keywords: Systematic review, Health promotion, Black minority ethnic groups, Physical activity, South Asian African

\section{Introduction}

Emerging evidence suggests that Black and Minority Ethnic (BME) groups have lower physical activity levels than their white counterparts and this may be one potential reason why BME groups are at higher risk of non-communicable diseases (Fischbacher et al. 2004; Haase et al. 2004; Health Survey for England 2004; Sport England 2006). Primary prevention of non-communicable diseases is paramount in public health in developed countries, and even more so for ethnic minorities. We use the United Kingdom (UK) as an example in this review as little is known about barriers to engaging in physically activity among BME groups in the UK and challenges of overcoming these barriers are critical in planning and implementing culturally sensitive interventions. 
Physical inactivity remains a major risk factor for chronic diseases and obesity. It is clear that having inactive lifestyles has contributed to increasing rates of heart disease, stroke, diabetes, depression and cancer, and to poor mental health (Adams et al. 2007; Alessio 1997; Cooper \& Brill 1988; Commandre et al. 2000; Santaularia 1995; Vuori 2001; Thompson 1994; Sproston \& Mindell 2006; Warburton et al. 2006). Globally, 1.9 million deaths are attributable to physical inactivity (WHO 2002a) and yet the proportion of people meeting recommendations of physical activity is generally low. In public health practice, recommendations are: 30 minutes of moderate-intensity physical activity 5 days per week or 20 minutes of vigorous-intensity physical activity 3 days per week for adults. The World Health Organisation (WHO 2002b) and evidence-based reviews by the American College of Sports Medicine and American Heart Association (Haskel et al. 2007), Strong et al. (2005) and Department of Health, UK (2004) supported this assertion. Of interest are findings in BME groups not meeting recommended activity levels as compared to general population (Fischbacher et al. 2004; Haase et al. 2004; Health Survey for England 2004; Health Education Authority 2000). In the same way, research has shown that ethnic minorities stand a higher chance of having non-communicable diseases in UK (NRCEMH 2004; Fischbacher et al. 2004; Haase et al. 2004; Rudat 1994). For instance, the prevalence rate of diabetes in BME groups is three to four times higher in Scotland's BME population (NRCEMH 2004, NRCEMH/Diabetes UK Scotland 2006) and the risk of heart disease in this group is higher than the general population (Bhopal 2000; Gill et al. 2004). Stroke mortality rates in African-Caribbean are up to four times higher than the general population in England and Wales (Chaturvedi \& Fuller 1996).

The BME groups are so diverse in terms of migration history, culture, language, religion and disease profiles. Defining 'ethnicity' is hard as the concept is multidimensional and used as a synonym for 'race' and there is no consensus on appropriate terms for use in the scientific study of health by ethnicity and race (Bhopal 2004). The term 'minority' may suggest a sociological group that does not constitute a politically dominant voting majority of the total population of a given society. They may be migrant, indigenous or landless nomadic communities. The term 'Black' is commonly referring to Africans and Afro-Caribbeans, but may also signify all non-white minority populations (Bhopal 2004), such as Indian, Pakistani, Bangladeshi and South Asian populations (Phillips 1998).

As physical activity inequalities may have resulted from barriers of participating in physical activity, commonly mentioned barriers in both BME groups and the general population are related to safety, availability, cost, personal barriers e.g. lack of time, health concerns, and lack of motivation. (Eyler et al.1998) and the social influence of peers (Keresztes et al. 2008). For BME groups 'restricting' factors such as culture, knowledge, strength of beliefs in health benefits of activity may be contributing (Haase et al. 2004). Increasing primary studies on physical activity issues among BME groups prompted this narrative review in order to give more dimension and insight into likely causes of physical activity inequalities. Overcoming these barriers is critical in developing and implementing interventions in multicultural environments.

\section{Objectives}

This review aims to undertake a narrative review of relevant literatures relating to barriers and influence involved in physical activity participation among BME groups.

Using a systematic approach will help to provide evidence of what is known about the dimension of barriers and influence to physical activity. This review brings together the findings of both quantitative and qualitative primary studies in the UK.

\section{Methods}

\subsection{Literature Search}

Five electronic bibliographic databases were searched from 1950 to April 2008, including MEDLINE, EMBASE, CINAHL, PsyINFO, Ethnicity and Health including government websites; NHS Scotland Library, Health Technology Assessments (HTA), National Institute of Health and Clinical Excellence (NICE). The review used combination of MeSH terms, free text word and truncated terms of 'physical activity', 'ethnic group', and 'barriers' were used in search strategy. The MEDLINE search strategy was adapted for searching other databases. Reference and library source searching plus hand-searches was also performed to identify relevant studies. A total of 391 articles and reports were identified.

\subsection{Study Selection}

Studies are included if they contained reported and separate BME groups results related to barriers or influence of physical activity in the UK. The sifting of literature performed in stages against inclusion criteria was initially based on 'title', and then 'abstract' that resulted in 71 potentially relevant references. The retrieved full texts of 71 references were similarly assessed to yield a total of 13 papers. Figure 1 summarises the sifting process with inclusion and exclusion criteria. Five papers were identified from hand-searched literature to make total of 18 papers that make up this systematic review.

A data extraction form was developed and piloted for the purpose of this review. Full data extraction was performed by one reviewer and checked by a second reviewer. The qualities of studies were assessed by nine-item checklist 
constructed specifically for this review (copy available from first author). The quality criteria were informed by several sources (Higgins 2006; Thomas et al. 2003; Spencer et al. 2003; NHS Centre for Reviews and Dissemination 1996, NHS Health Scotland 2008; Greenhalgh 1997). Discrepancies between reviewers were resolved through discussion.

\section{Findings}

\subsection{Description of Studies}

Findings are reported as narrative summary and in tabular form. The search strategy produced 391 articles. Out of these, 18 met the inclusion criteria of reporting separately the barriers of physical activity among BME Groups in the UK. The study designs of the included studies were of various types: nine studies used solely qualitative method, three were quantitative, and the remaining six studies used mixed method (Table 1). The qualitative studies employed methodologies that range from case studies to semi-structured interviews, and in-depth interviews to focus groups discussions. There were three intervention studies identified (Snape \& Binks 2008; Jolly et al. 2007; Carroll et al. 2002), one evaluated the intervention programmes by way of a RCT (Randomised Controlled Trial) (Jolly et al. 2007), while others gave case studies reports of the interventions. Sample sizes ranged from six to 175 in the qualitative studies, and from 25 to 4452 in the quantitative studies. All studies considered perspectives of BME groups although three papers included views from teachers (Khunti et al. 2007), programme staff (Snape \& Binks 2008), GPs (General Practitioners), Health Authorities and leisure centres (Carroll et al. 2002).

It is the aim of this review to consider only UK studies, we found that all papers were conducted in England except one (Lawton et al. 2006) which was conducted in Scotland. We also found that five of the studies expressed solely women's views and it is important to note that all these come from South Asian populations. One paper took its perspectives solely among men (Naeem 2001) and the rest included male and female. In the majority of studies the participants are adults above 18 years, only two studies explored the views of schoolchildren under the age of 15 (Khunti et al. 2007; Mahoney 1992).

The sample frames for included studies were drawn from variety of ethnic groups, settings and gender. Ethnicity was described by all the studies with 10 out of 18 papers restricted to South Asians mainly Indians, Pakistan, and Bangladesh (McKenna \& Ludwig 2008; Sriskantharajah \& Kai 2006; Carroll et al. 2002; Lawton et al. 2006; Khanam \& Costarelli 2008; Farooqi et al. 2000; Snape \& Binks 2008; Burney 2006; Khunti et al. 2007). Six studies combined mixed populations of South Asians, Whites and/or Afro-Caribbean (Greenhalgh et al. 1998; Mahoney 1992; Jolly 2007; Darr et al. 2008; Health Education Authority 1999; Rai \& Finch 1997) while one study each focused on Afro-Caribbean (Molokhia \& Oakeshott 2000) and West Africans (Elam et al. 2001). In methodological quality, the studies had clearly defined purpose and gave adequate descriptions of the sampling and justification for data collection in general, but details for sample validation and assessment of generalisability varied widely. There was limited evidence of triangulation with other sources and limitations of studies made clear by authors. Details of the studies' aims, design, samples and assessment of qualities are summarised in Table I and IV.

\subsection{Physical Activity Barriers}

Our review identified 20 barriers clustered among three broad themes of perceived personal, socio-cultural and environmental barriers. With no attempt to quantify results in this review, the range of barrier outcomes is appreciated (see Table III). Whilst some barriers are distinct, some are inter-related for example lack of time may be due to work or family commitment. Lack of time was the most reported barrier $(n=8)$ but further probing for reasons was poorly reported (Tables II and III).

Identifying literatures from databases have been difficulty as majority are qualitative studies which tend to use creative titles that provide no information on barriers of physical activity among BME groups. The included studies can be broadly classified into a) those that focus on physical activity alone $(n=8)$, and $b$ ) physical activity and other lifestyles $(\mathrm{n}=10)$. The groups included in the studies included patients with diabetes, cardiovascular heart disease (CHD), osteoporosis, and obesity. Studies were generally poorly reported and inconsistent questions asked to identify physical activity barriers. The physical activity preferences of BME groups were poorly explored by included studies.

\section{Discussion}

This review revealed a limited literature on physical activity among BME groups, and even less investigating the barriers to engaging in physical activities among the same UK population. Most studies explored the views of South Asian population as compared with other UK minorities. All studies conducted in England with exception of only one which was conducted in Scotland (Lawton et al. 2006). The information on methodology and results provided by most studies varied widely in terms of how it was presented and the level of details reported. This may be due to strict word-length restriction by some academic journals.

The difference in physical activity levels between BME groups and general population revealed by Fischbacher and colleagues may contribute to increase risks of non-communicable diseases such as diabetes, hypertension (Fischbacher et al. 2004). The strength of this review lies in providing better insight on the range of barriers that are consistently identified in several different studies related to BME groups. Knowledge of barriers to engaging in physical activity 
among this population may prove useful in the development of physical activity interventions for BME groups. The findings here are consistent with a review that focused on children in the general population (Brunton et al. 2003).

We identified inter-related personal, socio-cultural and environmental barriers as classified by several other studies (Andajani-Sutjahjo et al. 2004; Booth et al. 1997; Browson et al. 2001; Cleland et al. 2008). For example, personal barriers relate to lack of motivation; socio-cultural barriers are associated with lack of family support, religion, language barriers; and environmental barriers have to do with lack of information, access, safety, cost and time. Of interest is the cultural influence on physical activity in which participants negatively perceive exercise. In this case there were beliefs that exercise connotes 'illness', as informed by lay concept of exercise in Bangladesh's local language 'beyam' (Greenhalgh et al. 1998); the belief that women are not allowed to walk alone in the evening (Khanam \& Costarelli 2008); and also the perception of exercise as sexual connotation since it makes you look attractive for seduction purpose (Snape \& Binks 2008). The attitudes of participants towards physical activity were affected by other cultural factors such as language barriers, religion and cultural dress codes, unavailability of women only sessions at sport facilities.

Ruland and Moore (2001), Wilcox and colleagues (1999) and Burke and colleagues (2006) have all emphasized the influence of ethnic background on physical activity preferences. Our review pointed out lack of evidence as related to activity preferences. Understanding BME groups' preferences is crucial alongside evidence of barriers to physical activity in developing strategies of effective Physical Activity interventions.

This review falls short of assessing effectiveness of interventions used to promote physical activity among BME groups because only one study evaluated intervention promoting physical activity adherence (Jolly et al. 2007). The majority of studies were epidemiological and exploratory focusing on beliefs and attitudes towards healthy lifestyles and risks of diseases.

Challenges faced in searching for studies exploring the views of BME in UK may reflect either paucity of literature in this field or failures of search strategy to capture literature since creative titles not including keywords being used mostly. Hence, we cannot exclude the possibility of some studies being missed out in this review. A detailed quality assessment was not conducted in this review due to heterogeneity of study designs and the lack of consensus in the literature on quality criteria in use for mixed methods and qualitative studies (O'Cathain et al. 2008; Hannes 2008). As indicators of quality criteria in the field of Ethnicity and Health, we looked into justification for designs and sampling, ethical issues, language interpretation and triangulation of results with other sources. This is as informed by sources (Higgins 2006; NHS Health Scotland 2008; Thomas et al. 2003; Spencer I. 2003; University of York NHS Centre for Reviews and Dissemination 1996; Greenhalgh 1997. There is, however, a great need for development of standardised tools for assessing mixed methods.

The results of most of the studies may not be generalisable, this is more so because failure or inadequacy of the studies to include control groups, hence the result might have been over-interpreted.

\section{Conclusion}

This review has given more insights to potential causes of what is currently known in this field, namely that BME groups do have lower physical activity levels. Evidence of personal barriers, socio economic, cultural and environmental barriers that influence physical activities have been described in this paper. Overcoming these barriers in these broad areas is essential in development of sensitive multicultural health promotion addressing physical inequalities. Future research needs to focus on different contexts of physical activity preferences among BME groups as such evidence alongside the identified barriers to engaging in physical activity could help develop effective physical activity interventions targeted at BME groups. The paucity of literature in this field necessitates future research to take opportunity of including ethnic minorities in all research in UK with separate analysis, thus having foundation for more evidence and external validity of studies.

\section{References}

Adams, T., Moore M.T., \& Dye J. (2007). The relationship between physical activity and mental health in a national sample of college females. Women \& Health, 45, 69-85.

Alessio, H.M. \& Blasi, E.R. (1997). Physical activity as a natural antioxidant booster and its effect on a healthy life span. Research Quarterly for Exercise \& Sport, 68, 292-302.

Andajani-Sutjahjo, S.A., Ball, K., Warren N., Inglis, V. \& Crawford, D. (2004). Perceived personal, social and environmental barriers to weight maintenance among young women: A community survey. International Journal of Behavioural Nutrition and Physical Activity, 1, 15. Available from: http://www.ijbnpa.org/content/pdf/1479-5868-1-15.pdf [Dec 30, 2008].

Bhopal, R. (2000). What is the risk of coronary heart disease in South Asians? A review of UK research. Journal of Public Health Medicine, 22, 375 - 385.

Booth, M.L, Bauman, A., Owen, N. \& Gore, C. J. (1997). Physical activity preferences, preferred sources of assistance, and perceived barriers to increased activity among physically inactive Australians. Preventive Medicine, 26,131-137. 
Brownson, R.C., Baker, E.A., Housemann, R.A., Brennan, L.K. \& Bacak S.J. (2001). Environmental and policy determinants of physical activity in the United States. American Journal of Public Health, 91, 1995-2003.

Brunton, G., Harden, A., Rees, R., Kavanagh, J., Oliver, S. \& Oakley, A. (2003). Children and physical activity: a systematic review of barriers and facilitators. London: EPPI-Centre, Social Science Research Unit, Institute of Education, University of London.

Burke S.M., Carron A.V. \& Eys M. A. (2006). Physical activity context: Preferences of university students. Psychology of Sport and Exercise, 7, 1-13.

Burney, A. (2006). How physically active are Asians at work place NHS [Online]: Available: http://www.qactive.co.uk/publications/amir_burney_thesis [February 28, 2008].

Carroll, R., Ali, N. \& Azam, N. (2002). Promoting physical activity in South Asian Muslim women through exercise on prescription. Health Technology Assessment, 6, 8.

Cleland, V., Dwyer T., Blizzard L. \& Venn A., (2008). The provision of compulsory school physical activity: Associations with physical activity, fitness and overweight in childhood and twenty years later International Journal of Behavioural Nutrition and Physical Activity, 5, no. 14. [Online] Available: http://www.ijbnpa.org/content/pdf/1479-5868-5-14.pdf [Dec 30, 2008].

Commandre, F., Delarbre-Billard, M. \& Raybaud, A. (2000). Impact of physical activity on mental and physical health in the aged. Soins Gérontologie (French), 24, 8-11.

Cooper, K.H. \& Brill, P.H. (1988). Physical activity and health: the evidence is clear. World Health Forum. 9, 218.

Darr, A., Astin, F. \& Atkin, K. (2008). Causal attributions, lifestyle change, and coronary heart disease: illness beliefs of patients of South Asian and European origin living in the United Kingdom. Heart \& Lung, 37, 91-104

Department of Health UK. (2004). At least five a week; evidence on the impact of physical activity and its relationship to health. A report from the chief medical officer. London, Dept of Health.

Diabetes in Ethnic Minority Groups in Scotland. [Online] Available : http://www.nrcemh.nhsscotland.com/pdfs/leaflet\%20Diabetes.pdf [December 7, 2007].

Elam, G., McMunn, A. \& Nazroo J. (2002). Feasibility study for health surveys among black African people living in England: Final report - implications for the Health Survey for England 2003, London: The Stationery Office.

Eyler, A.A. Baker, E., Cromer, L., King, A.C. Brownson, R.C. \& Donatelle, R.J. (1998). Physical activity and minority women: a qualitative study. Health Education \& Behavior, 25, 640-652.

Farooqi, A., Nagra, D., Edgar, T. \& Khunti, K. (2000). Attitudes to lifestyle risk factors for coronary heart disease amongst South Asians in Leicester: A focus group study. Family Practice, 17, 293-297.

Fischbacher, C.M., Hunt, S. \& Alexander, L. (2004). How physical active are South Asians in United Kingdom? A literature review. Journal of Public Health, 26, 250-258.

Gill, P. S., Kai, J., Bhopal, R.S. \& Wild, S. (2002). Health Care Needs Assessment: Black and Minority Ethnic Groups. The epidemiologically based needs assessment reviews. Abingdon Radcliffe Medical Press Ltd. Available from: http://hcna.radcliffeoxford.com/bemgframe.htm.

Greenhalgh, P.M. (1997). Diabetes in British south Asians: nature, nurture, and culture. Diabetic Medicine, $14,10-18$.

Greenhalgh, T., Helman, C. \& Chowdhury, A. M. (1998). Health beliefs and folk models of diabetes in British Bangladeshis: A qualitative study. British Medical Journal, 316, 978-983.

Haase A., Steptoe, A., Sallis, J. F. \& Wardle, J. (2004). Leisure-time physical activity in university students from 23 countries: associations with health beliefs, risk awareness, and national economic development. Preventive Medicine, 39,182 .

Hannes K. (2008). Tools for Qualitative Studies. Cochrane Qualitative Research Method Group. [Online] Available: http://www.joannabriggs.edu.au/cqrmg/documents/Conference08/Critical\%20Appraisal.pdf [November 26, 2008].

Haskel W.L.,Lee I.M., Pate R.R., Powell K.E.,Blair S.N.,Franklin B.A.,Macera C.A.,Heath G.W.,Thonpson P.D.,Bauman A. (2007). Association Physical Activity and Public Health: Updated Recommendation for Adults from the American College of Sports Medicine and the American Heart Association. American College of Sports Medicine and the American Heart Association.

Health Education Authority. (2000). Black and Ethnic Minority groups in England: the second health and lifestyles survey. Health Education Authority, London.

Health Survey of England. (2004). The health of ethnic minority groups. [Online] Available: http://www.ic.nhs.uk/pubs/healthsurvey2004ethnicfull. [December 15, 2007]. 
Higgins, J.P.T. and Green, S. (2006). Cochrane Handbook for Systematic Review of Interventions 4.2.6. Online Cochrane Library. [Online] Available: www.cochrane.org/resources/handbook/hbook.htm [December 9, 2008].

Jolly, K., Taylor, R., Lip, G. Y., Greenfield, S., Raftery, J., Mant, J., Lane, D., Jones, M., Lee, K. W. \& Stevens, A. (2007). The Birmingham Rehabilitation Uptake Maximisation Study (BRUM). Home-based compared with hospital-based cardiac rehabilitation in a multi-ethnic population: cost-effectiveness and patient adherence. Health Technology Assessment, 11, 1-118.

Keresztes, N., Piko, B. F., Pluhar, Z.F. \& Page, R.M., (2008). Social influences in sports activity among adolescents. Journal of the Royal Society for the Promotion of Health, 128, 21-25.

Khanam, S. \& Costarelli, V. (2008). Attitudes towards health and exercise of overweight women. Journal of the Royal Society for Promotion of Health, 128, 26-30.

Khunti, K., Stone, M. A., Bankart, J., Sinfield, P., Pancholi, A., Walker, S., Talbot, D., Farooqi, A. \& Davies, M. J. (2008). Primary prevention of type-2 diabetes and heart disease: action research in secondary schools serving an ethnically diverse UK population. Journal of Public Health, 30, 30-37.

Lawton, J., Ahmad, N., Hanna, L., Douglas, M. \& Hallowell, N. (2006). I can't do any serious exercise: barriers to physical activity amongst people of Pakistani and Indian origin with Type 2 diabetes. Health Education Resources, 21, 43-54

Mahoney, C. (1992). 20-MST and PWC170 validity in non-Caucasian children in the UK. British Journal of Sports Medicine, 26, 45-47

McKenna, J. \& Ludwig, A.F. (2008). Osteoporotic Caucasian and South Asian women: A qualitative study of general practitioners' support. Journal of the Royal Society for the Promotion of Health, 128, 263-270.

Molokhia, M. \& Oakeshott, P. (2000). A pilot study of cardiovascular risk assessment in Afro-Caribbean patients attending an inner city general practice. Family Practice, 17, 60-62.

Naeem, A.G. (2003). The role of culture and religion in the management of diabetes: a study of Kashmiri men in Leeds. Journal of the Royal Society for Promotion of Health, 123, 110-116.

National Resource Centre for Ethnic Minority Health (2006). Focus on Diabetes; A guide to working with Blacks and minority communities in Scotland living with long term conditions. Diabetes UK Scotland.

National Resource Centre for Minority Ethnic Health (NRCEMH). 2004.

NHS Centre for Reviews and Dissemination. (1996). Ethnicity and health: reviews of literature and guidance for purchasers in the areas of cardiovascular disease, mental health and haemoglobinopathies. CRD Report 5. York: University of York.

NHS Health Scotland. (2008). Health in our multi-ethnic Scotland, Future Research Priorities. A draft consultation report of the Scottish Ethnicity and Health Research Strategy Working Group. Oct. 2008.

O'Cathain, A.,Murphy, E. \& Nicholl, J. (2008). The quality of mixed methods studies in health services research. Journal of Health Services Research \& Policy, 13, 92-98.

Rudat K. (1994). Black and Minority Ethnic Groups in England. Health and Lifestyle. Health Education Authority, London. [Online] Available: www.nice.org.uk/nicemedia/documents/black_minorities_england94.pdf [June 26, 2008].

Ruland C.M. \& Moore S.M. (2001). Eliciting exercise preferences in cardiac rehabilitation: Initial evaluation of a new strategy. Patient Education and Counseling, 44, 283-291.

Santaularia A. (1995). Physical activity and health. Benefits of exercising. Attention Primaria, 15, 574-579.

Scottish Health Survey, (2003). [Online] Available: http://www.scotland.gov.uk/Resource/Doc/924/0019811.pdf [December 4, 2008].

Snape, R. and Binks, P. (2008). Re-thinking sports; physical activity and healthy living in British South Asian Muslim communities. Managing Leisure, 13, 23-35.

Spencer, L., Ritchie, J., Lewis J. and Dillon, L. (2003). Quality in Qualitative Evaluation: A Framework for Assessing Research Evidence. Government Chief Social Researcher's Office, Cabinet Office, London. [Online] Available: http://www.policyhub.gov.uk/docs/a_quality_framework.pdf

Sport England. (2006). Active People Survey. [Online] Available: http://www.sportengland.org/index/get_resources/research/active_people.htm [November 27, 2008].

Sproston, K. \& Mindell, J. (2006). Health Survey for England 2004; the health of minority ethnic groups. London, The Information Centre. 
Sriskantharajah, J. \& Kai, J. (2007). Promoting physical activity among South Asian women with coronary heart disease and diabetes: What might help? Family Practice, 24, 71-76.

Strong, W.B., Malina, R.M., Blimkie, C.J.R., Daniels, S.R., Dishman, R.K., Gutin, B., Hergenroeder, A.C., Must, A., Nixon, P.A., Pivarnik, J.M., Rowland, T., Trost, S., \& Trudeau, F. (2005). Evidence based physical activity for school-age youth. Journal of Pediatrics, 146, 732-737.

Thomas, J., Sutcliffe, K., Harden, A., Oakley, A., Oliver, S., Rees, R., Brunton, V. \& Kavanagh, J. (2003). Children and Healthy Eating: A Systematic Review of Barriers and Facilitators. Social Science Research Unit, EPPI Centre, Institute of Education, University of London, London.

Thompson, W.G. (1994). Exercise and health: fact or hype? South Medical Journal, 87, 567-574.

Vuori, I. M. (2001). Health benefits of physical activity with special reference to interaction with diet. Public Health Nutrition. 4, $517-528$.

Warburton, D.E.R, Crystal, W.N. \& Shannon, S.D., (2006). Health Benefits of Physical Activity: the evidence. Canadian Medical Association Journal, 174, 801 -809.

Wilcox, S, King, A.C., Brassington G.S. \& Ahn D.K. (1999). Physical activity preferences of middle-aged and older adults: A community analysis. Journal of Aging \& Physical Activity, 7, 386-399.

World Health Organization (WHO). (2002a). The World Health Report 2002, Reducing Risks, Promoting Healthy Life. WHO, Geneva.

World Health Organization (WHO). (2002b). Diet and Physical Activity Fact sheet. [Online] Available: http://www.who.int/dietphysicalactivity/factsheet_recommendations/en/index.html [December 15, 2008].

Table 1. Characteristics of Studies included in the Systematic Review

\begin{tabular}{|c|c|c|c|}
\hline Reference & Design & Location & Ethnicity/Perspectives \\
\hline $\begin{array}{l}\text { Mckenna \& } \\
\text { Ludwig 2008 }\end{array}$ & $\begin{array}{l}\text { Qualitative method. } 22 \text { Semi-structured- interviews. } 43-82 \\
\text { years. Comparative study; Sample source; Osteoporosis } \\
\text { Society/support groups. Community setting. Analysis; Theme } \\
\text { generation manually. }\end{array}$ & $\begin{array}{l}\text { Bristol } \\
\text { England }\end{array}$ & $\begin{array}{l}\text { Female South Asian (Gujarati) \& Caucasians. } \\
\text { Perspective; Osteoporosis patients. Interviews were } \\
\text { mostly in English. Interpreter provided where } \\
\text { necessary.. }\end{array}$ \\
\hline $\begin{array}{l}\text { Sriskantharajah \& } \\
\text { Kai } 2006\end{array}$ & $\begin{array}{l}\text { Qualitative method.15 Semi-structured } \\
\text { Interviews, 26-70years. Sample source; GP list. Community } \\
\text { setting. Analysis; Theme generation. }\end{array}$ & $\begin{array}{l}\text { Nottingham } \\
\text { England. }\end{array}$ & $\begin{array}{l}\text { Female South Asian (Indian, Pakistan, Bangladesh, Sri- } \\
\text { Lanka). Perspective; CHD/NIDM patients. Interviews } \\
\text { mostly in English except for } 3 \text { where Interpreter was } \\
\text { used. Interpretation back checked. }\end{array}$ \\
\hline Caroll et al. 2002 & $\begin{array}{l}\text { Mixed method. Self administered Questionnaire, in-depth } \\
\text { interviews, focus groups, case studies of Pilot Intervention } \\
\text { programs. No evaluation by RCT.Sample; } 35 \text { South Asian } \\
\text { Muslim women. }\end{array}$ & $\begin{array}{l}\text { Bradford, } \\
\text { Leicester, East } \\
\text { Lancashire, } \\
\text { Birmingham }\end{array}$ & $\begin{array}{l}\text { South Asian Muslim women (Pakistan and } \\
\text { Bangladesh). Adults. Perspective; } 137 \mathrm{GPs}, 5 \text { Health } \\
\text { Authority, } 32 \text { Leisure centres, } 35 \text { South Asian Muslim } \\
\text { women. }\end{array}$ \\
\hline $\begin{array}{l}\text { Molokhia \& } \\
\text { Oakeshoot } 2000\end{array}$ & $\begin{array}{l}\text { Mixed method. Structured interviews with bio chemical risk } \\
\text { factors measurements. } 98 \text { respondents out of } 107(92 \%) .34 \\
\text { men, } 64 \text { women. Sample source; GP surgery attendance. } 10 \\
\text { patients }(9 \%) \text { attended } 3 \text { Focus groups. Age } 15-79\end{array}$ & $\begin{array}{l}\text { London } \\
\text { England }\end{array}$ & $\begin{array}{l}\text { Afro- Caribbean. } \\
\text { Perspective; CHD Patients. Interpreter-NR. }\end{array}$ \\
\hline Mahoney 1992 & $\begin{array}{l}\text { Quantitative method. Cohort study. } 103 \text { School children. } 53 \\
\text { boys, } 50 \text { girls. Age } 12 \text { years. School setting. }\end{array}$ & UK ? Region & Afro-Caribbean, Indians, races. Interpretation- NR \\
\hline
\end{tabular}




\begin{tabular}{|c|c|c|c|}
\hline Reference & Design & Location & Ethnicity/Perspectives \\
\hline Jolly et al. 2007 & $\begin{array}{l}\text { Mixed method. RCT ( } 263 \text { Home vs. } 262 \text { Hosp), } 43 \% \text { response } \\
\text { rate, } 6 \text { months follow up. } 49 \text { semis structured interviews for } \\
\text { non-adherers, } 5 \text { Focus groups for adhering patients. Outcomes; } \\
\text { Exercise capacity. Lack of motivation exists in home based, } \\
\text { group exercise is the motivation in hosp based. }\end{array}$ & $\begin{array}{l}\text { Birmingham } \\
\text { England }\end{array}$ & $\begin{array}{l}\text { Mixed; white, Pakistan, Indian, Afro-Caribbean. } \\
\text { Perspective; Cardiac rehabilitation patients. } \\
\text { Interpretation by rehabilitation nurse. }\end{array}$ \\
\hline Lawton et al. 2006 & $\begin{array}{l}\text { Qualitative method. } 32 \text { In-depth interviews } \\
\text { Age }>18 \text { years, Sample source; GP list. Analysis; Theme } \\
\text { generationNUDIST software }\end{array}$ & $\begin{array}{l}\text { Edinburgh } \\
\text { Scotland }\end{array}$ & $\begin{array}{l}9 \text { Indian, } 23 \text { Pakistan. Perspective; Diabetes patients. } \\
\text { Bilingual researcher interprets in Urdu, Punjabi. }\end{array}$ \\
\hline $\begin{array}{l}\text { Khanam \& } \\
\text { Costarelli } 2008\end{array}$ & $\begin{array}{l}\text { Mixed method. A survey based on interview-guided } \\
\text { questionnaires. } 25 \text { subjects. Age.30-60years. Sample source; } \\
\text { sport centre/mosque. Results expressed in quotations and } \\
\text { percentage. }\end{array}$ & $\begin{array}{l}\text { London } \\
\text { England }\end{array}$ & $\begin{array}{l}25 \text { Muslim Bangladesh females. Perspective; } \\
\text { Overweight women referred to gym by GP. Bilingual } \\
\text { researcher in Syhelti. }\end{array}$ \\
\hline $\begin{array}{l}\text { Farooqi et al. } \\
2000\end{array}$ & $\begin{array}{l}\text { Qualitative method.6 Focus groups. } 44 \text { subjects participated. } \\
\text { Age }>40 \text { years. Sample source; GP list. Analysis; Theme } \\
\text { generation. }\end{array}$ & $\begin{array}{l}\text { Leicester } \\
\text { England }\end{array}$ & $\begin{array}{l}\text { South Asian female. Perspective; Women thought to be } \\
\text { at high risk of CHD. Interpreter in Hindi, Gujarati, } \\
\text { Punjabi. Back translation checked. }\end{array}$ \\
\hline Darr et al. 2008 & $\begin{array}{l}\text { Qualitative method. Comparative study. } 65 \text { Semi-structure } \\
\text { interviews. } 65 \text { out of } 122 \text { subjects (response rate } 83 \% \text { ), } \\
\text { Age }>30 \text { years. Sample source; Cardiac rehabilitation nurses. }\end{array}$ & $\begin{array}{l}\text { West Yorkshire } \\
\text { England }\end{array}$ & $\begin{array}{l}20 \text { Pakistan, } 25 \text { Indian, } 20 \text { White. Perspective; CHD } \\
\text { patients diagnosed in last } 1 \text { year.. Translation in Urdu, } \\
\text { Hindi, Punjabi, Sylheti, Gujarati. }\end{array}$ \\
\hline $\begin{array}{l}\text { Snape \& Binks } \\
2008\end{array}$ & $\begin{array}{l}\text { Qualitative method. Case studies of intervention program in } \\
\text { Blackburn North Healthy Living Centre. Semi-structured } \\
\text { interviews with program staff focus groups with community } \\
\text { members. Facility attracted } 4353 \text { subjects over I year mostly } \\
\text { Asian community; No evaluation by RCT. }\end{array}$ & $\begin{array}{l}\text { Blackburn } \\
\text { England }\end{array}$ & $\begin{array}{l}\text { South Asian Muslim; } 1887 \text { Indians, } 1903 \text { Pakistan and } \\
4 \text { Bangladesh. Perspectives from program staff and } \\
\text { community members. Translation interpretation by } \\
\text { program staff. }\end{array}$ \\
\hline Nacem 2001 & $\begin{array}{l}\text { Quantitative method. Questionnaire-Survey, } 106 \text { out of } 160 \\
\text { men responded. Sample source; Diabetes Clinic list. Analysis by } \\
\text { SPSS. }\end{array}$ & $\begin{array}{l}\text { Leeds } \\
\text { England }\end{array}$ & $\begin{array}{l}\text { Kashmir Muslim, } 106 \text { men. Perspective; Diabetic } \\
\text { patients. Bi-lingual researcher }\end{array}$ \\
\hline
\end{tabular}

\begin{tabular}{|l|l|l|l|}
\hline Reference & Design & Location & Ethnicity/Perspectives \\
\hline $\begin{array}{l}\text { Burney 2006 } \\
\text { (Unpublished) }\end{array}$ & $\begin{array}{l}\text { Mixed method. Self-administered Questionnaires -survey; 47 } \\
\text { out of 345 (13.6\% response rate). 6 semi-structured interviews. }\end{array}$ & $\begin{array}{l}\text { Nottingham } \\
\text { England }\end{array}$ & $\begin{array}{l}\text { South Asians; 37 Indian, 10 Pakistan. Perspective; } \\
\text { NHS staff- Workplace. Researcher is fluent in Hindi, } \\
\text { Gujarat, and Punjabi. }\end{array}$ \\
\hline HEA 1999 & $\begin{array}{l}\text { Quantitative method. Questionnaire survey, 4452 subjects. } \\
\text { (Response rate 72\%). Sample source; Postcode Address File. }\end{array}$ & England & $\begin{array}{l}\text { Pakistan, Indian, Bangladesh, Afro-Caribbean. } \\
\text { Interpretation by interviewers. }\end{array}$ \\
\hline Khunti et al. 2007 & $\begin{array}{l}\text { Mixed method. Comparative study called action research project } \\
\text { for a year period. No specific intervention but collaborative } \\
\text { links established.Questionnaires-4763 pupils in 5 schools, } \\
\text { Response rate 3601, 76\% at baseline, 8 Focus groups.5 school } \\
\text { settings. }\end{array}$ & $\begin{array}{l}\text { Leicester } \\
\text { England }\end{array}$ & $\begin{array}{l}\text { 3650 pupils out of 4763 are south Asians77\%, mostly } \\
\text { Indians. Age 11-15years, Perspective; Pupils and staff. } \\
\text { Interpreter-NR }\end{array}$ \\
\hline $\begin{array}{l}\text { Rai \& } \\
\text { Finch 1997 }\end{array}$ & $\begin{array}{l}\text { Qualitative method. 22 Focus groups. 175 total respondents. } \\
\text { Gender specific groups. Age 18-50years. Analysis; Theme } \\
\text { generation }\end{array}$ & $\begin{array}{l}\text { London } \\
\text { England }\end{array}$ & $\begin{array}{l}\text { Indians, Bangladesh, Pakistan, African Blacks. } \\
\text { Translator in Punjabi, Urdu, Gujerati, Syheti }\end{array}$ \\
\hline Elam et al. 2001 & $\begin{array}{l}\text { Qualitative method.48 In-depth interviews. 44 participated in 4 } \\
\text { focus groups. }\end{array}$ & $\begin{array}{l}\text { London, } \\
\text { Manchester } \\
\text { England }\end{array}$ & African; Ugandans, Somalia, Nigerians \\
\hline
\end{tabular}


Table 2. Findings of Studies' Barrier outcomes

\begin{tabular}{|c|c|c|}
\hline Reference & Aim of studies & Barriers Outcomes \\
\hline $\begin{array}{l}\text { Mckenna \& } \\
\text { Ludwig } 2008\end{array}$ & $\begin{array}{l}\text { Comparative study of views and experience between } \\
\text { Osteoporotic Caucasian and south Asian women about GPs' } \\
\text { support. Results; Asians reliance on GP, family and } \\
\text { community for support and resources. }\end{array}$ & $\begin{array}{l}\text { Uncertainty on source of information. } \\
\text { No referral by GP. }\end{array}$ \\
\hline $\begin{array}{l}\text { Sriskantharajah \& } \\
\text { Kai } 2006\end{array}$ & $\begin{array}{l}\text { To explore influences and attitudes towards physical } \\
\text { activity among south Asians CHD and DM patients. }\end{array}$ & Health concems, Lack of knowledge \\
\hline Caroll et al. 2002 & $\begin{array}{l}\text { To explore attitudes and practices of 'exercise on } \\
\text { prescription' among south Asian women, GP, leisure } \\
\text { centres and authorities. }\end{array}$ & $\begin{array}{l}\text { Access to facilities, cost, no childcare support, cultural codes of conduct, } \\
\text { language. }\end{array}$ \\
\hline $\begin{array}{l}\text { Greenhalgh et al. } \\
1998\end{array}$ & $\begin{array}{l}\text { To explore health beliefs and experience of management in } \\
\text { Bangladesh DM patients. }\end{array}$ & $\begin{array}{l}\text { Safety, Lack of knowledge. No facilities. Negative perception as lay concept } \\
\text { of exercise connotes illness'beyam' Women only sessions }\end{array}$ \\
\hline $\begin{array}{l}\text { Molokhia \& } \\
\text { Oakeshoot } 2000\end{array}$ & Cardiovascular risk assessment & $\begin{array}{l}\text { Lack of time especially in women with children. } \\
\text { Lack of risk awareness. Language difficulty }\end{array}$ \\
\hline Mahoncy 1992 & $\begin{array}{l}\text { Cardiovascular fitness measurement using 20-MST and } \\
\text { PWC170. }\end{array}$ & Religion, Language and dress code \\
\hline Jolly et al. 2007 & $\begin{array}{l}\text { Trial of patient adherence and cost effectiveness when } \\
\text { Home based rehabilitation centre compared with hospital } \\
\text { based. }\end{array}$ & Health problem, Lack of motivation, Distance too far to centre. \\
\hline
\end{tabular}

\begin{tabular}{|c|c|c|}
\hline Reference & Aim of studies & Barriers Outcomes \\
\hline Lawton et al. 2006 & $\begin{array}{l}\text { Barriers of physical activity among Pakistan and Indians with Type } \\
2 \text { Diabetes. }\end{array}$ & $\begin{array}{l}\text { Lack of time, Health concerns, weather, Language difficulties, Lack } \\
\text { of culturally sensitive facilities }\end{array}$ \\
\hline $\begin{array}{l}\text { Khanam \& } \\
\text { Costarelli } 2008\end{array}$ & $\begin{array}{l}\text { Attitudes towards health and exercise of overweight and obese } \\
\text { women }\end{array}$ & $\begin{array}{l}\text { Language, lack of time, lack of motivation, cultural reasons- } \\
\text { provocative videos, lack of knowledge, women not allowed to walk } \\
\text { alone/ in the evening }\end{array}$ \\
\hline $\begin{array}{l}\text { Faroogi et al. } \\
2000\end{array}$ & $\begin{array}{l}\text { Attitudes to lifestyle risk factors for coronary disease among South } \\
\text { Asians }\end{array}$ & Lack of women only facilities, lack of time, religion, language \\
\hline Darr et al. 2008 & $\begin{array}{l}\text { Causal attributions, illness belief of CHD South Asian patients in } \\
\text { UK. }\end{array}$ & $\begin{array}{l}\text { Lack of time, lack of understanding, health problems and fear, } \\
\text { weather, no access to open spaces for walking. job }\end{array}$ \\
\hline $\begin{array}{l}\text { Snape \& Binks } \\
2008\end{array}$ & $\begin{array}{l}\text { Factors identified in developing PA intervention Muslim South } \\
\text { Asian community. }\end{array}$ & $\begin{array}{l}\text { Exercise perceived as neglect of family responsibility, religion, } \\
\text { concern about negative impact, } \\
\text { sexual connotation since it makes you look attractive, dress code, } \\
\text { sexual safety. }\end{array}$ \\
\hline
\end{tabular}

\begin{tabular}{|l|l|l|}
\hline Naeem 2001 & The role of culture and religion in management of Diabetes & $\begin{array}{l}\text { Cost, fear of injury or safety, dress code, lack of single sex facilities, } \\
\text { lack of privacy in changing areas }\end{array}$ \\
\hline Burney 2006 & $\begin{array}{l}\text { Levels of physical active and barriers among South Asians at } \\
\text { workplace }\end{array}$ & $\begin{array}{l}\text { Lack of time, commitment to work, working unusual hours, } \\
\text { obligations to family, childcare. }\end{array}$ \\
\hline HEA 1999 & Black and minority ethnic groups survey in England & $\begin{array}{l}\text { Old age, lack of time, lack of motivation, fear of injury/safety, health } \\
\text { problem, not sporty, cost, no partner }\end{array}$ \\
\hline Khunti et al. 2007 & $\begin{array}{l}\text { Primary prevention of type 2 diabetes and heart disease. In } \\
\text { secondary schools. Evaluating action research project. }\end{array}$ & $\begin{array}{l}\text { Low priority of impact of PA on health, lack of storage for bikes in } \\
\text { facilities, religion, limitation by availability of staff in extracurricular } \\
\text { activities }\end{array}$ \\
\hline $\begin{array}{l}\text { Rai \& } \\
\text { Finch } 1997\end{array}$ & $\begin{array}{l}\text { Views of Physical activity among south Asians and black } \\
\text { communities in England. }\end{array}$ & $\begin{array}{l}\text { Lack of motivation, lack of company, fear about safety, single sex } \\
\text { facilities, dress code, cost constraints, work, lack of time, religion. }\end{array}$ \\
\hline Elam et al. 2001 & $\begin{array}{l}\text { Feasibility study for health surveys among black African people in } \\
\text { England 2003 survey. }\end{array}$ & Concerns about weight gain, encouragement from friends. \\
\hline
\end{tabular}


Table 3. Classification of Barriers

\begin{tabular}{|c|c|c|c|}
\hline & Barriers & Reference & Number of Ref. \\
\hline 1 & $\begin{array}{l}\text { Uncertainty on source of } \\
\text { information }\end{array}$ & Mckenna 2008 & 1 \\
\hline 2 & No referral by GP. & Mckenna 2008, Khanam 2008, Elam 2001 & 3 \\
\hline 3 & $\begin{array}{l}\text { Health concerns e.g. fear of } \\
\text { injury }\end{array}$ & Sriskantharajah 2006, Lawton 2006, Darr 2008, Naeem 2001, HEA 1999, Elam 2001 & 6 \\
\hline 4 & Lack of knowledge & Sriskantharajah 2006, Greenhalgh 1998, Molokhia 2000, Khanam 2008, Darr 2008. & 5 \\
\hline 5 & $\begin{array}{l}\text { Access to facilities e.g. far } \\
\text { distance or inadequate facilities. }\end{array}$ & $\begin{array}{l}\text { Caroll 2002, Greenhalgh 1998, Lawton 2006, Farooqi 2000, Darr 2008, Naeem } \\
\text { 2001.Khunti 2007. }\end{array}$ & 7 \\
\hline 6 & Cost constraints & Caroll 2002, Naeem 2001, HEA 1999, Rai 1997 & 4 \\
\hline 7 & $\begin{array}{l}\text { Family obligation e.g. no } \\
\text { childcare support }\end{array}$ & Caroll 2002, Burney 2006, & 2 \\
\hline 8 & Dress code & Caroll 2002, Mahoney 1992, Khanam 2008, Snape 2008, Naeem 2001, Rai 1997 & 6 \\
\hline 9 & Language barrier & $\begin{array}{l}\text { Caroll 2002, Molokhia 2000, Mahoney 1992, Lawton 2006, Khanam 2008, Farooqi } \\
\text { 2000, Darr 2008. }\end{array}$ & 7 \\
\hline 10 & $\begin{array}{l}\text { Safety and fear e.g. avoidance of } \\
\text { crime/sexual abuse }\end{array}$ & Greenhalgh 1998, Snape 2008, Naeem 2001, HEA 1999, Rai 1997 & 5 \\
\hline 11 & $\begin{array}{l}\text { Negative perception as lay } \\
\text { concept of exercise }\end{array}$ & Greenhalgh 1998, Snape 2008 & 2 \\
\hline 12 & Lack of time & $\begin{array}{l}\text { Molokhia 2000, Lawton2006, Khanam 2008, Farooqi 2008, Darr 2008, Burney2006, } \\
\text { HEA 1999, Rai } 1997\end{array}$ & 8 \\
\hline 13 & Religion & Mahoney 1992, Farooqi 2000, Snape 2008, Rai 1997, Khunti 2007 & 5 \\
\hline 14 & Lack of motivation, low priority & Jolly 2007 , Khanam 2008, HEA 1999, Rai 1997, Khunti 2007 & 5 \\
\hline 15 & Weather condition & Darr 2008 & 1 \\
\hline 16 & $\begin{array}{l}\text { Culturally sensitive facilities e.g. } \\
\text { videos, music }\end{array}$ & Khanam 2008, Lawton 2006 & 2 \\
\hline 17 & Lack of women only sessions & Caroll 2002, Nacem 2001, Faroogi 2008, Khanam 2008, Rai 1997 & 5 \\
\hline 18 & $\begin{array}{l}\text { Commitment to work e.g. } \\
\text { working unusual hours }\end{array}$ & Burney 2006, Rai 1997 & 2 \\
\hline 19 & $\begin{array}{l}\text { No accomplice, partner or group } \\
\text { exercise }\end{array}$ & $\begin{array}{l}\text { Sriskantharajah 2006, Carool 2002, Lawton 2006,Jolly 2007, HEA 1999, Rai 1997, } \\
\text { Elam 2001. }\end{array}$ & 7 \\
\hline 20 & Age & HEA 1999, & 1 \\
\hline
\end{tabular}


Table 4. Quality Criteria of Studies

\begin{tabular}{|c|c|c|c|c|c|c|c|c|c|c|}
\hline Study & 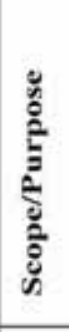 & $\begin{array}{l}\frac{5}{3} \\
0 \\
0\end{array}$ & $\frac{e}{\mathrm{E}}$ & 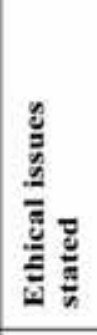 & 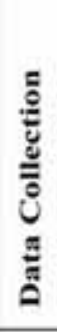 & 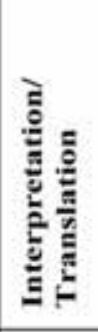 & $\frac{n}{\frac{n}{n}}$ & 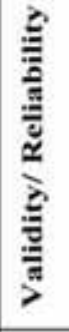 & 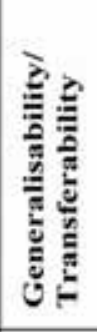 & 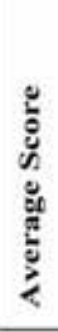 \\
\hline Mckenna \& Ludwig 2008 & + & + & $\sim$ & + & + & $\sim$ & - & $\sim$ & $\sim$ & 6.0 \\
\hline Sriskantharajah \& Kai 2006 & + & $\sim$ & + & - & + & + & - & $\sim$ & $\sim$ & 5.5 \\
\hline Caroll et al. 2002 & + & + & + & + & + & $\sim$ & + & $\sim$ & + & 8.0 \\
\hline Greenhalgh et al. 1998 & + & + & + & $\sim$ & + & + & $\sim$ & $\sim$ & + & 7.5 \\
\hline Molokhia \& Oakeshoot 2000 & + & + & + & $\sim$ & - & - & $\sim$ & - & $\sim$ & 4.5 \\
\hline Mahoney 1992 & + & + & $\sim$ & - & $\sim$ & - & + & + & $\sim$ & 5.5 \\
\hline Jolly et al. 2007 & + & + & $\sim$ & $\sim$ & $\sim$ & + & $\sim$ & + & + & 7.0 \\
\hline Lawton et al. 2006 & + & + & + & $\sim$ & $\sim$ & $\sim$ & $\sim$ & + & $\sim$ & 6.5 \\
\hline Khanam \& Costarelli 2008 & + & $\sim$ & + & $\sim$ & $\sim$ & $\sim$ & $\sim$ & $\sim$ & $\sim$ & 5.5 \\
\hline Farooqi et al. 2000 & + & + & + & - & + & + & $\sim$ & $\sim$ & $\sim$ & 6.5 \\
\hline Darr et al. 2008 & + & + & + & $\sim$ & $\sim$ & $\sim$ & $\sim$ & $\sim$ & + & 6.5 \\
\hline Snape \& Binks 2008 & $\sim$ & + & $\sim$ & - & - & $\sim$ & - & $\sim$ & $\sim$ & 3.5 \\
\hline Naeem 2001 & + & $\sim$ & + & $\sim$ & $\sim$ & $\sim$ & $\sim$ & $\sim$ & - & 5.0 \\
\hline Burney 2006 & + & $\sim$ & + & $\sim$ & $\sim$ & $\sim$ & + & $\sim$ & $\sim$ & 6.0 \\
\hline HEA 1999 & + & $\sim$ & + & $\sim$ & + & $\sim$ & + & + & + & 7.5 \\
\hline Khunti et al. 2007 & + & $\sim$ & + & + & + & - & + & + & + & 7.5 \\
\hline Rai \& Finch 1997 & + & + & + & + & + & $\sim$ & + & + & + & 8.5 \\
\hline Elam et al. 2001 & + & + & $\sim$ & - & $\sim$ & - & $\sim$ & $\sim$ & $\sim$ & 4.5 \\
\hline
\end{tabular}




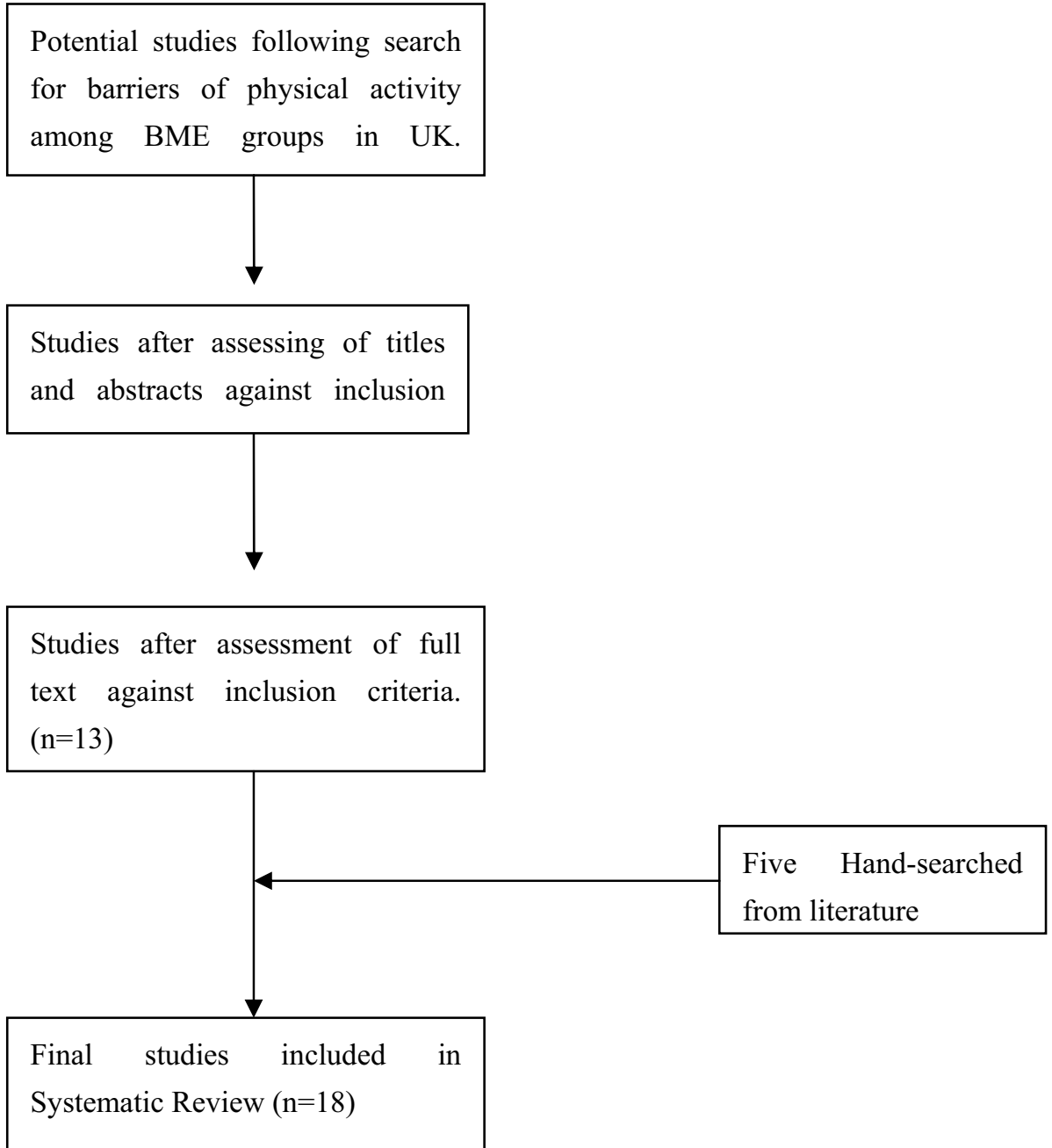

Figure 1. Flow diagram: Searching and sifting process 